\title{
Paradigm of the Common Economic Space Formation in the Context of Globalization
}

\author{
Innessa Efremenko \\ Professor, Doctor of Economic Sciences, Rostov State University of Economic, Rostov-on-Don, Russia \\ Email: efremenko@yandex.ru \\ Taniana Panasenkova
}

Professor, Doctor of Economic Sciences, Rostov State University of Economic, Rostov-on-Don, Russia

Email:p_tania_@mail.ru

Natalya Vovchenko

Professor, Doctor of Economic Sciences, Rostov State University of Economic, Rostov-on-Don, Russia Email: nat.vovchenko@gmail.com

\section{Doi:10.5901/mjss.2015.v6n3s6p155}

\section{Abstract}

Objective: Economic integration is one of the defining trends of the global economy due to the growing process of internationalization of economic activities. The purpose of this research is to identify the key parameters of the process of economic integration in the post Soviet space in the context of globalization. Methods: Any cross-national integration association suggests a development of the mechanism to manage the processes that go beyond the nation-state. Within the framework of economic integration the management mechanisms of the process of globalization which contribute to building of the effective relationships between the two countries to strengthen their competitive position in the global arena are being formed. The countries' integration associations serve as "building blocks" of the emerging system of global governance the world economy. Results and conclusions: The processes of integration in the post-Soviet space have features that are revealed in the asymmetric nature of the interaction of the countries participating in the association where Russia is a dominant center as well as actual reintegration nature of the association of the post-Soviet space, which is a unique example of developing of the integration interaction in the global economy. In this context, It is necessary to define the institutions to regulate the economic systems as well as to understand which level of development such institutions should reach to make post-Soviet countries' integration acquire an in-depth nature and to become an economic phenomenon.

Keywords: economic integration, regulation, globalization, institutional approach

\section{Introduction}

Studies of the institutional aspects of the regional economic integration began in 1980-90-s with neo-institutional approach, whose founders were Keohane (1986), Ruttberger (1993), Pierson (1996), Bulmer (1997), Hix (1998), and others. According to this approach the international integration is one of the ways to create the optimal structure of international relations under global interdependence based on the formation of new international formal and informal institutions (as opposed to national), organizations and international regimes that promote coordination to solve the economic problems. The integration process requires the creation of new institutions with decision-making mechanisms and the modification of existing policy instruments to meet the centralized management requirements (Pierson, 1996).

\subsection{Pros and cons of integration processes}

Active integration processes in the globalizing world economy bring about positive changes and promote international trade in the framework of the emerging blocks, unions and communities. However, it is necessary to single out and organize not only advantages but disadvantages of economic integration as well (Table. 1). Despite the current negative effects of the economic integration, the countries seek economic convergence, which is reflected in the implementation of joint goals, obtaining economic benefits due to the access to the world markets. Moreover, the globalization processes do not allow countries to remain isolated from the integration processes. 
Table 1. Advantages and disadvantages of economic integration in the context of international trade development

\begin{tabular}{|l|l|l|}
\hline Criterion & Advantages & Disadvantages \\
\hline $\begin{array}{l}\text { The reduction of tariff and non-tariff } \\
\text { barriers }\end{array}$ & $\begin{array}{l}\text { promotes trade and expand consumer } \\
\text { range of products; } \\
\text { elimination of the administrative barriers } \\
\text { while the abolition of customs controls } \\
\text { inside the block }\end{array}$ & $\begin{array}{l}\text { establishment of preferential tariffs under a } \\
\text { regional association leads to inefficient trade } \\
\text { ("trade deflection") }\end{array}$ \\
\hline the market increase & $\begin{array}{l}\text { increase the number of the potential } \\
\text { buyers by eliminating barriers that } \\
\text { impede access to the market; } \\
\text { increased competition in the markets in } \\
\text { the single economic space }\end{array}$ & asymmetry among the parties \\
\hline $\begin{array}{l}\text { Export development within the } \\
\text { association }\end{array}$ & $\begin{array}{l}\text { expansion integration association on a } \\
\text { global scale; } \\
\text { gaining a competitive advantage in the } \\
\text { markets of other countries }\end{array}$ & $\begin{array}{l}\text { dependence of the level of economic security } \\
\text { on the level of the dominant industry in the } \\
\text { export sector is being formed }\end{array}$ \\
\hline $\begin{array}{l}\text { Formation of cross-border industrial } \\
\text { relations }\end{array}$ & $-\begin{array}{l}\text { promotes export of finished products } \\
\text { outside the region }\end{array}$ & reducing level of economic security \\
\hline $\begin{array}{l}\text { Strengthening of the political and } \\
\text { economic institutions of the } \\
\text { countries participating in the } \\
\text { integration associations }\end{array}$ & $-\begin{array}{l}\text { delegation of some powers to } \\
\text { supranational bodies of the regulation; } \\
\text { improvement and liberalization of the } \\
\text { business environment }\end{array}$ & $\begin{array}{l}\text { complex (multi-level) structure of the regulatory } \\
\text { system }\end{array}$ \\
\hline
\end{tabular}

Source: compiled and systemized by the authors

The existing mechanisms of the economic integration can be adapted for both non-competitive and for weakly competitive national economies to involve them in the global economy. This approach will be studied in detail as well as the criteria to assess the possible adaptation of institutional innovation in the process of integration management will also be identified.

\subsection{The evolution of the forms of economic integration}

With a certain degree of conditionality the following state-legal forms (stages) of the creating of the integration associations are usually singled out: 1) free trade zone; 2) customs union; 3) common market; 4) Economic Union (Kovalyov, 2007). It is necessary to clarify that currently a clear legal interpretation of the term "single economic space" has not been given in the field of the international law that allows a number of researchers to correlate it with the concept of "economic union" and to define as the highest form of economic integration (Vishnyakov, 2007).

In practice, the stage of conclusion of the preferential trade agreements is a preparatory stage of the institutional realization of the forms of the integration, i.e. the formation of a free trade zone, customs union, common market and a common economic space.

These trade agreements create more favorable trade regimes for the countries. At this stage it is possible to speak about the formation of a single economic space without creating any institutions to regulate this process.

The "free trade zone" is one of the forms and mechanisms of economic integration, facilitating the transition to a deeper level of economic cooperation among the countries in the world economy.

Almost all the agreements on free trade zone at the early stages are characterized by incomplete mode which is manifested in the existing differences in levels of economic development of the countries participating in the integration associations as well as the ability of domestic producers to adapt to the changing conditions of trading. In this regard, there are three target model of free trade in the world (Table. 2).

The formation of a free trade zone is the initial step in creation of a common economic space. The free trade zone is one of the types of international economic integration. 
Table 2. Models of the free trade in the global economy

\begin{tabular}{|c|c|c|}
\hline Model & Examples & Brief description \\
\hline $\begin{array}{l}\text { The deep integration model, which } \\
\text { assumes transition to the customs union, } \\
\text { common market, economic and } \\
\text { monetary union in these countries }\end{array}$ & $\begin{array}{l}\text { 1. European Economic Community; } \\
\text { 2. The Eurasian Economic Community } \\
\text { (EurAsEC) }\end{array}$ & $\begin{array}{l}\text { The centers of gravity of international trade } \\
\text { flows are being formed which suggests the } \\
\text { unification of institutional conditions to } \\
\text { regulate trade regimes }\end{array}$ \\
\hline $\begin{array}{l}\text { The model, which provides preparation } \\
\text { and adaptation to join the other } \\
\text { integration associations }\end{array}$ & $\begin{array}{l}\text { 1. Central European Agreement on Free } \\
\text { Trade Area (CEFTA); } \\
\text { 2. Agreement between the Western } \\
\text { Balkan countries }\end{array}$ & $\begin{array}{l}\text { The institutional environment for the trade } \\
\text { integration into the existing integration } \\
\text { associations is being formed }\end{array}$ \\
\hline $\begin{array}{l}\text { The model which did not require } \\
\text { integration with other structures or } \\
\text { transition to more advanced forms of } \\
\text { integration }\end{array}$ & $\begin{array}{l}\text { 1. European Free Trade Association } \\
\text { (EFTA); } \\
\text { 2. The North American Free Trade } \\
\text { Agreement (NAFTA) }\end{array}$ & $\begin{array}{l}\text { High degree of freedom to form and change } \\
\text { foreign economic priorities, as well as the } \\
\text { opportunity to transit to other integration } \\
\text { models is retained }\end{array}$ \\
\hline
\end{tabular}

Source: compiled by the author

This suggests that the customs duties in the countries-participants and the restrictions in mutual trade are abolished, free movement of goods and services produced in the territory of the member countries of free trade zone is set, preserving national sovereignty (Mantusov, 2002).

The countries-participants of the free trade zone agree on tax rate applicable to mutual trade and develop the rules of trade with other countries outside the free trade zone. As a rule, the functioning of the free trade zone is determined by a specially constituted interstate secretariat established in one of the Member States.

The next form of economic integration is the customs union, i.e. an agreement on the abolition of customs duties involving two or more states, the elimination of national tariffs, as well as the establishment of a common customs tariff to trade with third countries, which all together suggests the formation of the common customs area.

A single customs territory is created by establishing a unified customs tariff and a common external customs borders with the third countries outside the customs union. Functioning of the single customs territory involves the creation of supranational institutions of regulation, holding common customs policy as well as defining the rules of trade among countries both within the integration association and outside it.

The world experience of development of international relationships among countries shows that a customs union, as a form of economic integration, creates favorable conditions for the development of trade, production, and also helps to strengthen economic, political relations of states united by common economic interests.

A growing number of customs unions in the global economy under globalization, the expansion and strengthening of their positions on the world arena testify that this form of economic integration brings significant benefits to the countries involved in the integration processes. Union allows the countries to present one integrated economic and political bloc in the international relations, gives impetus to the development of national economies of the countriesparticipants of the customs union, enhances their competitive position in the global economy, as well as offers great opportunities for businesses integrating countries.

The success of the customs unions is largely determined by formulation and implementation of joint objectives to develop and strengthen of national economies through participation in integration associations, as well as the development of new mechanisms of economic cooperation under the increasing global economic integration processes.

At present, the integration processes function successfully and dynamically in different parts of the world, which is manifested in the formation of free trade zones, and the customs unions based on them.

The Common Market of South America (MERCOSUR) is one of the largest and fastest growing economic and political organizations in the world economy, the full scale customs union, the creation of which was an important step in the development of the integration processes in Latin America.

One of the similarities of MERCOSUR and the Customs Union of Belarus, Kazakhstan and the Russian Federation is a significant difference in the sizes of the economies as well as the dominance of one country in relation to the other participating countries. A distinctive feature of the organizational structure of MERCOSUR is that there is no supranational regulatory authority in this regional union all the decisions are made by consensus.

Another integration union in the world is the Cooperation Council for the Gulf, characterized by a significant asymmetry between the member countries of the association. A distinctive feature of this association is the strong dependence of the participating countries on the export of oil and gas (the proportion of hydrocarbons in the total exports 
of Saudi Arabia exceeds 90\%), which affects the volume of intra-regional trade. The Gulf Cooperation Council has highly integrated infrastructure, including the national grid and the single pipeline network to transport natural gas, which is beneficial for the development of trade. Since 2008, this integration association has been operating as a common market, ensuring smooth movement of goods, capital and labor. Thus, the integration in this region is associated with the development of a common infrastructure, the liberalization of mutual access to the service market as well as expansion of the investment flows.

The Treaty on establishing a single customs territory and formation the Customs Union between Belarus, Kazakhstan and Russia on its basis of October 6, 2007 contains the following definition of the Customs Union - a form of trade and economic integration, having a single customs territory, within which the mutual trade in goods, occurring both within a single customs territory and in the third countries and released into free circulation in the customs territory, customs duties and economic restrictions are not applied, except the special protective, antidumping and countervailing measures.

In contrast to other international organizations, the Customs Union of Belarus, Kazakhstan and Russia is not an international organization, it is essential that these countries association is defined as a form of trade and economic integration of the EurAsEC member states. On the territory of the Customs Union apply a common customs tariff and other common measures regulating trade with third countries.

The next step for the integration of the customs union is a common market which technically means that the free movement of factors of production - labor, capital and financial resources is added to the free movement of goods within the customs union. The part of the resources already involved in the production process belongs to the factors of production [4]. In this regard, at a certain stage of development of the customs union along with the presence of the free movement of goods and services it is necessary to create the free movement of production factors that contribute to the transformation of the customs union into the common market.

As we have pointed out above a number of researchers identify the concept of "economic union" as the highest form of economic integration and the "single economic space". To understand the concept of "common economic space" let us consider the existing theoretical approaches.

According to modern scientists-economists, such as Harry S., E. Heckscher, Paul Samuelson, M. Porter, the formation of a common economic space is connected with the increasing globalization of the world economy as well as with international and social division of labor. In the works of R. Doshaev (2005), K. Blochin (2007), E. Pluchevskaya (2004), a single economic space is a single territory with a certain system of economic relations, the subjects of these relations, common regulatory framework, authorities and fiscal authorities, currency, common market of goods, services, technology, capital and labor, operating under the effective competition, a single central bank and the conditions for the movement of people and goods.

Describing the common economic space from the perspective of legal scholars, A.A. Kovalev (2007) argues that, along with the general customs tariffs and freedom of movement of factors of production, it also provides the coordination of the macroeconomic policy and harmonization of legislation in the key areas - currency, fiscal, monetary. Thus there is a need to set the supranational institutions empowered to make quick decisions on behalf of the integration association as a whole, as well as to conduct coherent macroeconomic policies of the participating countries of the integration association.

V.G. Vishnjakov (2007) compares a single economic space with a particular organization that has a two-tier structure - general economic mechanisms operating in several countries, and organizational and legal forms of the association, coordination and management of these economic mechanisms within a single organization.

When forming a single economic space the participating countries conduct common policy to unify the legal framework of functioning of the single economic space. In contrast to the customs union while forming and functioning of a single economic space supranational institutions are created which do not only regulate trade policies, but also coordinate all aspects of economic activities of the association that characterizes the a single economic space as the highest form of regional economic integration.

Thus, the analysis of theoretical approaches to the notion "single economic space" shows that it is a form of organization of a single services market, capital and labor. The single economic space involves the creation of common rules in the field of investment, competition policy, antitrust, subsidies, and government procurement, thereby contributing to the development of entrepreneurship in all areas. According to many experts and analysts, a single economic space is the synergy of all parties involved, aimed at a positive result for all together and individually. 


\section{The Impact of Globalization on the Processes of Economic Integration}

The formation of a single economic space is a reaction to the impact of globalization. Globalization creates the internal sources for the development; stimulates the integration processes due to the unequal position of member countries with respect to each other. Under the influence of globalization, the world economy is becoming a more common form of integration that requires organizing a global international cooperation.

The globalization process of the world economy and the increasing interdependence of countries due to regional integration give a powerful impetus to the development of economic systems at different levels of economic interaction. The differences do not allow the countries to develop a single model of economic integration; therefore there are many regional economic blocs, associations and unions, intertwined with various forms of international economic integration in today's world.

In the new economic conditions, the process of developing the world economic relations has determined the need for modification of the model of economic integration not only in developed countries, but also in developing ones, which need to have the access to the world markets, obtain scarce resources, as well as more favorable terms of trade due to insufficient level of economic development.

\subsection{Models of economic integration}

Under the increasing globalization processes, the international economic integration has gained new features, a trend towards consolidation of integration associations and the emergence of new models of multiformat, multi-speed and transcontinental integration including are among them. In various regions of the world the groups of countries have initiated a variety of integration projects and initiatives designed to provide a deeper relationship of national economies (Bogomolov, 2003). The peculiarities of interaction among the national economies manifested in the modification of the existing and developing of new models of the economic integration determine the result of integration.

In his research A. Limbman concludes that "the model of economic integration" is a sustainable combination of the three main integration processes in a particular region: the players with specific interests and resources, the processes of interaction of the players and the institutional environment regulating these processes (Liebman, 2009). Despite the specific, unique features and characteristics, the model of economic integration are based on a common international phenomenon, allowing countries to integrate in order to improve their competitive advantages.

At present, the domestic researchers the following model of economic integration are distinguished, which differ in scope and objectives of the integration association (Table. 3).

Table 3. Models of economic integration

\begin{tabular}{|l|l|}
\hline Model of economic integration & Integration Association \\
\hline Model of political and economic integration & the European Union (EU) \\
\cline { 2 - 2 } & The Eurasian Economic Community (EurAsEC) \\
\cline { 2 - 2 } & Association of South-East Europe (ASEAN) \\
\cline { 2 - 2 } & The Shanghai Cooperation Organization (SCO) \\
\cline { 2 - 2 } & Southern Common Market (MERCOSUR) \\
\cline { 2 - 2 } Model of trade and economic cooperation & Caribbean Community (CARICOM) \\
\hline \multirow{5}{*}{ regulating trade and tariff policies } & the European Free Trade Association (EFTA) \\
\cline { 2 - 2 } & North American Agreement on Free Trade Area (NAFTA) \\
\cline { 2 - 2 } & The Organization of Petroleum Exporting Countries (OPEC) \\
\hline & the World Trade Organization \\
\cline { 2 - 2 } & $\begin{array}{l}\text { Organization for Economic Co-operation and Development } \\
\text { (OECD) }\end{array}$ \\
\cline { 2 - 2 } & Asia-Pacific Economic Cooperation (APEC) \\
\cline { 2 - 2 } & $\begin{array}{l}\text { United Nations Conference on Trade and Development } \\
\text { (UNCTAD) }\end{array}$ \\
\hline Model of political alliances and military blocs & The North Atlantic Treaty Organization (NATO) \\
\cline { 2 - 2 } & The South American Community of Nations (YUNASUR) \\
\cline { 2 - 2 } & Collective Security Treaty Organization (CSTO) \\
\hline
\end{tabular}

Source: compiled by the author 
In recent years, there is a tendency to form new models of economic integration, directed to the creation of a transcontinental scale integration associations through the agreements on the free trade zone among the groups located on different continents, and located outside the region.

The European Union demonstrates the experience of creating such integration associations. So, in 1995, the EuroMediterranean free trade zone was established at the Barcelona Conference with participating of the EU and 10 countries of the Middle East and North Africa. In 2008 the agreements on economic partnership among the EU and integration associations of African, Caribbean and Pacific (ACP countries) came into force. The agreements designed to stimulate regional integration and economic progress within the ACP group. The new format of cooperation foresees the EU's refusal from unilateral preferences in favor of ACP countries and the transition to the principle of reciprocity, cooperation in the field of investment and standards, regulation of competition and public procurement (Dalgov, 2006). Thus, the formation of the EU-ACP transcontinental free trade zone with the elements of a single integrated market is supposed to have been finished by 2020.

In addition to the transcontinental economic integration model there are multi-format and varying-speed integrations. The example of such a model of the integration processes are the processes taking place in the post-Soviet space. Established in 2000 the powerful integration grouping - the Eurasian Economic Community, which unites Belarus, Kazakhstan, Kyrgyzstan, Russia and Tajikistan has a multi-format and varying-speed character of developing of the integration links. On the basis of the Eurasian Economic Community, Belarus, Kazakhstan and Russia have moved into a new form of economic integration - the Customs Union, and since 1 January, 2012 to a single economic community. This integration grouping is the most successful example of the formation of economic cooperation in the post-Soviet space.

The emergence of new, more flexible integration models (varying-speed, multi-format, transcontinental) allows conclude that regional integration has favorable prospects for further development of the existing models of economic integration in a globalizing world economy.

The model of the economic integration in North America is different from the models of integration in the Western Europe and Asia, based on the harmonized regulatory activity in many industrialized countries. In other associations the integration was exercised from top to bottom when intergovernmental agreements stimulated business contacts from different countries. In the North American group, on the contrary, the process of integration was "bottom-up": first the inter-company communication reached high-level, and then intergovernmental agreements based on these were made (Ozhigina \& Chaykovskaya, 2005).

Some researchers have denied the existence of integration in North America due to significant differences in its manifestations in comparison with other integration processes taking place in the world (Lavrovsky, 1987). However, after the Canada-US Free Trade Agreement (FTA) was signed and subsequently the NAFTA, the model of integration in the region became more like the model of the European Union. Since that moment the integration agreements on free trade based on the idea of "open regionalism", the principle of regional integration organization of economic cooperation, implying the mobilization of global resources to solve regional problems became widespread in the world. Integration relationships based on the "open regionalism" type are either bilateral or group character, and in most cases the states with asymmetrical power become their members.

Inside NAFTA, unlike the EU and APEC, there is only one center of economic power - the United States, whose economy is several times larger than Canada and Mexico economies combined. Such a model makes it easier to control (the leading countries can easily impose their solutions to the weaker partners), but at the same time the environment for potential conflicts is created (the US partners may be dissatisfied with their subordinate position). In addition, integration is lopsided: Canada and Mexico are closely integrated with the United States, but not with each other.

The asymmetric nature of the relationship among the NAFTA countries and the lack of political superstructure were the main features of this association. The specific model of the integration in the region is characterized by the model of well-known formula "hub-and-Spoke (s)" ("sleeve - spokes"), in which the hegemonic country (the USA) performs the role of a central hub ("hub") and their relationship with Canada and Mexico are presented as the spokes of the wheels (Komkova, 2011). In recent years, this model is becoming more common in the world, becoming the organizational form of trade and economic agreements between the countries involved.

Different levels of the development of the national economies of the integrating countries in the post-Soviet space defines the possibility for the Customs Union of Russia, Belarus and Kazakhstan to use the experience of the North American model of economic integration in the designing of integration ties in the post-Soviet space.

It should be noted that the countries of the analyzed associations are on a higher level of integration - the development of the united economic space. However, it should be noted that there are general characteristics of the interaction (integration) of the countries of the Customs Union. The integration processes in the analyzed associations are implemented according to the model of economic integration, characterized by the dominance of one country 
(Russia) among the weaker neighbors (Kazakhstan, Belarus) both economically and politically. This model of integration interaction allows countries to perform basic communication through the "hegemonic country" with a slight communication among each other.

\subsection{The impact of globalization on the evolution of models of economic integration}

In a globalizing world economy many countries to initiate a process of regional integration aimed at a more in-depth relationship of national economies. The effectiveness of this interaction is largely determined by the desire to achieve a new level of economic development, which leads to the formation of dominance and at different stages of development of globalization processes, the different models of economic integration.

The integration processes have become particularly pronounced due to the internationalization of economic life and the increasing globalization of the world economy. In the presented stages of globalization formed various integration associations, but more distinctly traced the development of integration in Western countries, as evidenced by the formation of the European Union. In the early 90-ies of XX century, the European Union is the dominant model of economic integration that has reached in its development the highest stage of integration, forming a monetary union.

Since the late 90-s. the strengthening of economic integration, which is manifested in the formation of a variety of different integration groups, dynamic in a globalizing world economy is traced. Currently, there is a tendency to deepen the integration of the former Soviet Union, which resulted in the formation of the economic integration model with the asymmetric nature of the interaction in the association - the Eurasian Economic Community, on the basis of which the members of the organization formed the Customs Union and are developing the Common Economic Space.

\section{Conclusions}

Current models of regional associations allow benefit from the integration of the countries with different levels of economic development. The less developed countries are integrated with the highly developed ones, forming blocks and integration associations, thus bringing their level of economic and political development to closer to the level of the developed countries, thereby accelerating the process of adaptation of the developing countries to the globalization of the world economy.

In the context of the globalization processes of the world economy the participation of national economies in the international integration processes is intensified. Under these conditions, there is a strengthening of economic relations at the regional level. The transformation of the world political structure brings about a transition from a bipolar world, with the supposed dominance of two superpowers (Dergachev, 2004), to the multipolar world order, based on the growing role of regional organizations and gravitating to the emerging "poles" (North American agreement on free trade, 2015) and having an impact on the trend of world economic development.

It could be argued that the current stage of development of the world economy is characterized by uncertain prospects for world economic growth against the backdrop of the center of global economic activity from West to East, from America and Europe to Asia, from developed to developing regions. This leads to an increase in the influence of large emerging economies and regional integration alliances with their participation in the global economic development.

\section{References}

Blochin K.A. (2007). Influence of the foreign trade communications of the region on development of a common economic space of Russia (on the example of Krasnodar Krai). Cand.Econ.Sci. of M.

Bulmer S. (1997). New institutionalism and the governance of the single European market//J. of European public policy. Vol. 5, No. 3. P. 365-386.

Bogomolov O. T. (2003). Anatomiya's mantises of global economy, - M.: Akademkniga. P. 88.

Customs union as basis of a common market of the European community. (2015). Accessed on: http://www.simst.bsu.by/main/ departments/law/staff/ignatyuk/publications/1.pdf

Dalgov D. S. (2006). Evolution of forms and stages of regional economic integration in the conditions of globalization.//Russian external economic messenger. No. 6.

Dergachev V.A. (2004). Geoekonomichesky dictionary reference. — Odessa, Ipreei to a nan, 2004. - 177s.

Doshayev R. M. (2005). A common economic space - an integration form in the conditions of the market. M.: Synergy.

Hix S. (1998). The study of European Union II; new governance' agenda and its rival//J. of European public policy. Vol. 5, No. 1. - P. 3865.

Keohane R. (1986). Neorealism and its critics. N.Y.: Columbia university press. 378p. 
Komkova E.G. (2011). Canada in processes of North American economic integration: teoretiko-methodological aspect. - M.: ISKRAN. Kovalyov A.A. (2007). International economic law and legal regulation of the international economic activity. - M.: Scientific book.

Lavrovsky T.V. (1987). Severoamerikanskaya integration. Economic and political aspects. - Moscow. Science. P. 11.

Liebman A.M. (2009). Models of economic integration: world and Post-Soviet experience.

Mantusov V. B. (2002). The main problems, the directions and the mechanism of integration intra regional cooperation in the CIS. Avtoref. yew. ... Dr.Econ.Sci. - Moscow.

North American agreement on free trade. Krugosvet's encyclopedia (2015). Accessed on: http://www.krugosvet.ru/enc/gumanitarnye nauki/ekonomika_i_pravo/SEVEROAMERIKANSKOE_SOGLASHENIE_O_SVOBODNO_TORGOVLE_NAFTA.html

Ozhigina V. V., Chaykovskaya YU.V. (2005). Institutional aspects of regional integration of countries with economies in transition (on the example of the Common economic space) // Problems of modern economy and the institutional theory. Release 89-2. Pp. 129135.

Pierson P. (1996). The path to European integration; historical institutionalism perspective//Comparative political studies. Vol. 29 , No. 2. - Pp. 123-163.

Pluchevskaya E.V. (2004). The movement to the Common Economic Space as a condition of integrity of Russia. Avtoref. yew. ... Cand.Econ.Sci. Tomsk.

Ruttberger V. (1993). Regime theory and international relations. - Oxford: Clarendon press, New York: Oxford university press. - $470 \mathrm{p}$. Velyaminov G. M. (2004). International economic law and process. - M.: Volters Kluver.

Vishnyakov V. G. (2007). Pravo and Common economic space. Educational and scientific practical work. - M.: RAGS. 